\title{
Third Party Suspicion of Lack of Authority on the Part of Company Agents - A Comparative Study and a Suggested Rule
}

\author{
Bede Harris ${ }^{1}$ \\ ${ }^{1}$ School of Accounting and Finance, Charles Sturt University, Australia \\ Correspondence: Bede Harris, School of Accounting and Finance, Charles Sturt University, Locked Bag 119, \\ Kingston Act 2604, Australia. E-mail: beharris@csu.edu.au
}

Received: March 10, 2015 Accepted: April 1, 2015 Online Published: May 27, 2015

doi:10.5539/jpl.v8n2p98 URL: http://dx.doi.org/10.5539/jpl.v8n2p98

This article is dedicated to the late Professor Alastair Kerr, Dean of the Faculty of Law, Rhodes University, who first inspired in me an interest in the law of agency.

\begin{abstract}
A risk affecting $3^{\text {rd }}$ parties entering into contracts with companies is whether the representative of the company has authority to enter into the transaction, and whether that person has complied with internal company procedures. In the common law world these issues are governed by the law of agency and the 'internal management rule' respectively. In the People's Republic of China (PRC) applicable rules are found in the Contract Law and the Company Law. Recent decades have seen a divergence in approaches in the common law world, with the common law retained in some jurisdictions and superseded by legislation in others. This has led to differences in the law, particularly with respect to the critical issue of under what circumstances $3^{\text {rd }}$ parties contracting with company representatives lose the right to assume that the representative has the authority they appear to have or, to state the issue differently, what level of knowledge or suspicion of irregularity a company should prove a $3^{\text {rd }}$ party has in order to avoid liability for the acts of the company's agent. These differences have significant implications for inter-jurisdictional contracts. This article examines the law in Singapore, Hong Kong, Australia, New Zealand and the PRC and assesses the extent to which the rules in each jurisdiction satisfactorily balance the interests of companies and third parties and serve the interest of commercial convenience. It notes that the approaches in Singapore and Hong Kong, which both retain the common law, and in the PRC, which has independently developed almost identical rules, strike the appropriate balance between the rights of companies and $3^{\text {rd }}$ parties contracting with them, whereas statutory formulations in Australia and New Zealand do not. The article concludes with a model formulation of applicable rules which, if adopted, would remove uncertainty in this area.
\end{abstract}

Keywords: agency, agent, authority, company, corporation, estoppel, Turquand

\section{Introduction - The Common Law Position}

When a $3^{\text {rd }}$ party enters into a transaction with an agent of company, the validity of the contract depends on whether the company's agent had the requisite authority to enter into the transaction. An additional issue that may arise is whether, even if the transaction does fall within the agent's authority, the agent has complied with any internal procedures that might be required by the company's internal governing document.

Under the common law, the first of these issues - whether the company's agent has authority - is governed by the law of agency, which recognises that an agent may have express, implied or ostensible (apparent) authority. (Note 1) Disputes most frequently arise in cases where authority is apparent - that is, when the company's agent lacks authority, but the circumstances are such that, through its acts or omissions, the company has caused the $3^{\text {rd }}$ party reasonably to believe that that the agent has authority. (Note 2)

The second issue - whether an agent with some type of authority has complied with internal company proceedings regulating its exercise - is governed by the 'indoor management' rule, established in the famous case of Royal British Bank v Turquand, (Note 3) (hereafter referred to as Turquand), in which the court held that the third party is entitled to assume that an agent of a company has the authority which the company holds them out as having, even if the exercise of that authority is subject to some internal restriction has not been fulfilled. In 
other words, the $3^{\text {rd }}$ party may presume that internal formalities have been complied with and does not have to inquire whether they have in fact been complied with. However, the Turquand rule will not work in favour of a $3^{\text {rd }}$ party who has knowledge - either actual or deemed - of the fact that the agent lacks authority. The key question in those circumstances is what amounts to 'knowledge'. This is an important issue, give that the entry into contracts with corporations is an every day event. Furthermore, where there are differences between the law of different jurisdictions, failure to appreciate these differences can be a trap for the unwary $3^{\text {rd }}$ party dealing with agents of a company.

This article examines the state of the law in five jurisdictions in the Asia-Pacific region: Hong Kong, Singapore, Australia, New Zealand and the People's Republic of China (PRC), critically evaluating the rules of law in each. Given the frequency with which companies enter into inter-jurisdictional contracts (and in particular the frequency with which this occurs between companies in these jurisdictions), and the advantages that would flow from a uniform approach, the article ends with a model rule which, it is argued, best serves fairness both to companies and $3^{\text {rd }}$ parties dealing with them and the interest of commercial convenience.

\section{Hong Kong}

Under Hong Kong law, contracts made by companies are governed by s 121 of the Companies Ordinance (Cap 622). The section confers on companies the same contractual capacity as is enjoyed by natural persons, and states that such contracts may be entered into in writing or orally (Note 4) by a person acting with the company's authority, whether express or implied. No mention is made of company agents acting with apparent authority, nor does the statute address the circumstance where an agent's express or implied authority is subject to a qualification of which the $3^{\text {rd }}$ party is unaware. Therefore these issues continue to be governed by the common law as developed in Hong Kong.

The Turquand rule was most recently referred to in Hong Kong in Akai Holdings Ltd (In Liquidation) $v$ Thanakharn Kasikorn Thai Chamkat (Mahachon) also known as Kasikorn Bank Public Co Ltd (Note 5) (the Akai case). In this case, Mr Ting, the Chief Executive Officer of the appellant company, Akai, had entered into a loan on behalf of that company and, when asked by the respondent bank, Kasikorn, which was to lend the money for evidence of his authority to sign the contract, he had presented a forged document which purported to be a copy of the minutes of the company's Executive Committee. The Court of Final Appeal, per Lord Neuberger of Abbotsbury NPJ held (Note 6) that a $3^{\text {rd }}$ party will be unable to rely on the apparent authority of a company agent, where the third party's belief was 'dishonest or irrational (which includes turning a blind eye and being reckless)'. He also held that the Turquand rule can be relied on by a third party dealing with a company agent only once the third party has established some sort of authority on the part of the agent (Note 7) and that in determining whether a third party can rely on the rule, a test of the reasonableness of the third party's steps in determining the facts is applied. (Note 8)

In the event, in this case this case, the court never reached the point of having to apply the Turquand rule. This was because the respondent bank failed to establish any form of authority on the part of the appellant's purported agent, Mr Ting. The bank conceded that Mr Ting, had no actual authority because he had forged the company executive company minutes which purported to show that he had authority to enter into the transaction. The respondent therefore had to prove that that Mr Ting had had apparent authority - in other words, that the appellant company had held him out as having authority. Neuberger LJ held that (Note 9)

It is clear that, as executive chairman and chief executive officer of Akai, Mr Ting would have had a large measure of apparent authority - indeed, no doubt he would have had a large measure of actual authority. That authority would, no doubt, extend to entering into many types of contract, including, I would have thought, contracts which might involve Akai incurring a \$ 30 million liability.

Neuberger NPJ then went on to say (Note 10) that the issue in the case was whether the extraordinary nature of the transaction took it outside the ambit of its purported agent's apparent authority - in other words, that it was unreasonable for the respondent to have believed that the agent had apparent authority to enter into that specific transaction. Neuberger LJ noted two facts which made the transaction unusual and which would have been apparent to the bank: the fact that it was of no benefit to the appellant on whose behalf Mr Ting was acting (Note 11) and that because the bank was aware that Mr Ting had an interest in the company in whose favour the transaction did work, it would have known that he was in a position of conflict of interest. On this basis he held that it was not reasonable for the bank to believe that Mr Ting had had apparent authority to enter into the transaction. (Note 12)

Thus although in Akai the court ultimately did not need to apply the Turquand rule, the case does show that in Hong Kong the test applied by the courts in determining whether a third party is deprived of the protection of the 
rule is an objective one - that is, whether a reasonable person in the position of the $3^{\text {rd }}$ party would have been put on their inquiry.

\section{Singapore}

In Singapore company contracts are regulated by s 23 of the Companies Act (Cap 50), which provides as follows:

\section{Capacity and powers of company}

23.-(1) Subject to the provisions of this Act and any other written law and its memorandum or articles of association, a company has -

(a) full capacity to carry on or undertake any business or activity, do any act or enter into any transaction; and

(b) for the purposes of paragraph (a), full rights, powers and privileges.

The Act contains no specific provision regarding the authority of company agents, and so this area continues to be governed by the common law.

This was most recently affirmed in Skandinaviska Enskilda Banken AB (Publ), Singpore Branch v Asia Pacific Breweries (Singapore) Pte Ltd, (Note 13) (the SEB case) Ean J cited with approval (Note 14) academic authority (Note 15) in which it is stated that the circumstances in which the Turquand rule will not be available to a $3^{\text {rd }}$ party are where (i) the contracting party knows or should know of the agent's lack of authority, (ii) the nature of transaction is such as to put the third party on their inquiry as to the agent's authority, in which case if the $3^{\text {rd }}$ party does not make reasonable inquiries, no estoppel will arise in his favour or (iii) the circumstances are such that a reasonable man would be suspicious of the agent's authority.

\section{Australia}

In Australia, prior to the enactment of ss 128-129 of the Corporations Act 2001 (Cth), the position was governed by the common law rule that a $3^{\text {rd }}$ party loses the right to rely on the Turquand rule in circumstances where the $3^{\text {rd }}$ party was 'put on his inquiry'. This rule, originally stated in Morris $v$ Knassen (Note 16) was applied in Australia by the High Court in Northside Developments Pty Ltd v Registrar-General. (Note 17) In that case, a director and the company secretary of the appellant had entered into a transaction in terms of which they pledged the company's major asset as security for a bank loan in favour of an unrelated company in which they had an interest. The court in Northside applied the objective test found in Turquand - that a $3^{\text {rd }}$ a party will be denied the protection of the Turquand rule if the circumstances were such that a reasonable person would have made inquiries as to whether the purported agent of a company had authority. (Note 18) On the facts of the case the court held that although the director and company secretary appeared to have authority and appeared to have validly affixed the company's seal to the contract, the bank lost the right to assume that the seal had been validly affixed because a reasonable $3^{\text {rd }}$ party in the position of the bank would have suspected that the agents might not have authority, given that the bank was aware that the transaction was of no benefit to the company, and ought therefore to have inquired as to whether authority did in fact exist.

The common law has now been put into statutory form in Australia by ss 128-129 of the Corporations Act 2001 (Cth). Section 128(1) entitles $3^{\text {rd }}$ parties to make certain assumptions in dealings with a company. The assumptions are listed in s 129. Most relevant for current purposes is the assumption contained in s 129(3), which is as follows:

(3) A person may assume that anyone who is held out by the company to be an officer or agent of the company:

(a)has been duly appointed; and

(b)has authority to exercise the powers and perform the duties customarily exercised or performed by that kind of officer or agent of a similar company.

The effect of these provisions is to incorporate into the Act the common law rules of agency as they pertain to contracts entered into on behalf of corporations, along with the protection afforded to $3^{\text {rd }}$ parties by the Turquand rule.

Even though it may be common practice for $3^{\text {rd }}$ parties to seek confirmation of an agent's authority in the form of a minute from a meeting of the board of directors, (Note 19) that does not mean that failure to do so amounts to unreasonableness by the $3^{\text {rd }}$ party. The purpose of ss $128-129$ is to entitle a $3^{\text {rd }}$ party to assume that the matters listed in s 129 are true without making any inquiry. 
However, the critical difference between the common law and the statutory regime is that under s $128(4)$, a $3^{\text {rd }}$ party will be denied the right to assume that an agent of a company has authority only where the $3^{\text {rd }}$ party "knew or suspected" that the assumption of authority they were relying on was not true - in other words, where they subjectively knew or suspected lack of authority. It is no longer enough for a company seeking to avoid liability to discharge the objective test of showing that the $3^{\text {rd }}$ party where a reasonable person would have suspected lack of authority and failed to inquire further. The company has to prove actual knowledge or suspicion. (Note 20)

While it is true that a court can infer what a person "must have known" in the circumstances, and that may include taking into account what a reasonable person in those circumstances would, or ought, to have known, (Note 21) the fact remains that what a reasonable person would have known or suspected cannot be equated with what a particular $3^{\text {rd }}$ party actually suspected, and a denial by a $3^{\text {rd }}$ party that they actually knew or suspected lack of authority is obviously far more difficult to overcome than an assertion by them that they could not reasonably have known or suspected something.

The Explanatory Memorandum which accompanied the legislation which inserted s 128(4) into the Act is of little assistance in understanding the provision. The Explanatory Memorandum contained only the following brief sentence relating to the provision: (Note22)

This objective test is stricter than the current law and makes it clear that the common law "put on inquiry" test has no application to the statutory provisions.

This statement is less than helpful. It contains an internal contradiction, in that the first phrase in the sentence describes the test in s 128(4) as being objective (whereas it is clearly subjective) and yet the second phrase states that the (objective) "put on inquiry" test no longer applied after the enactment of s 128(4). (Note 23)

The fact that s 128(4) is tested subjectively and not objectively has been affirmed in the two cases in which it has been interpreted. In Oris Funds Management Ltd v National Australia Bank Ltd (Note 24) Osborn J held

..I adopt the understanding of the word 'suspect' addressed by Kitto J in Queensland Bacon Pty Ltd $v$ Rees

'In the first place, the precise force of the word 'suspect' needs to be noted. A suspicion that something exists is more than a mere idle wondering whether it exists or not; it is a positive feeling of actual apprehension or mistrust, amounting to 'a slight opinion, but without sufficient evidence', as Chambers Dictionary expresses it'

I do not accept that s 128(4) is concerned with cases of constructive knowledge or constructive suspicion.

Thus Osborn J was clearly of the view that s 128(4) required that actual, subjective suspicion be proved, and that constructive suspicion - that is, what a reasonable person ought to have suspected - was not sufficient to trigger its operation. Similarly, in Sunburst Properties Pty Ltd v Agwater Pty Ltd (Note 25) Gray J stated

Section 128(4) appears to place the burden on the company to establish the person's subjective knowledge or suspicion that the section 129 assumptions relied on were incorrect. That is to say, a person does not lose the benefit of the assumptions in section 129 merely because the person's suspicions, in the circumstances, should have been aroused. In this respect, the operation of section $128(4)$ can be contrasted with the "put on inquiry" test that applies when a person seeks to enforce a defective contract at common law.

The defect in the subjective test is that it places too heavy a burden on a company seeking to avoid liability in comparison to the common law, in that providing evidence to show that a reasonable person would have been put on their inquiry (the common law requirement), the company now has to provide sufficient evidence to show that the $3^{\text {rd }}$ party must themselves actually have suspected lack of authority - which poses a significantly higher hurdle. In addition, the subjective test also encourages $3^{\text {rd }}$ parties not to inquire in circumstances where a reasonable person in their position would have.

\section{New Zealand}

The position in New Zealand is governed by s 18(1) of the Companies Act 1993 (NZ). Section 18(1)(a) - (e) lists a number of assertions that a company may not make against a person dealing with it. These include that either the Companies Act or the company's internal governing document have not been complied with; that a person named as a director of the company has not been duly appointed and that a person held out as a director, employee or agent of the company has not been duly appointed or does not have the authority which a director, employee or agent of a company carrying on the business which the company is conducting would customarily 
exercise. The final clause of s 18(1) states that the only circumstance in which a company can make such an assertion is if

the person [that is, the person dealing with the company] has, or ought to have, by virtue of his or her position with or relationship to the company, knowledge of the matters referred to in any of the paragraphs (a), (b), (c), (d) or (e).

The use of the word 'ought' in the proviso means that a $3^{\text {rd }}$ party will be denied the protection of s 18(1) if the either actually knew that the fact they were relying on was not true or ought, objectively, to have known that. Although this wording appears to be consistent with the common law 'put on inquiry' test, the proviso has been interpreted as requiring that the company prove a higher level of knowledge in the mind of the $3^{\text {rd }}$ party than was required under the common law. In Equiticorp Industries Group Ltd (in stat man) v Attorney-General (No 47) (Note 27) Smellie J referred (Note 28) to the five levels of knowledge formulated in the English case of Baden, Delvaux and Lecuit v Societe General pour Favoriser le Development du Commerce (Note 29) in which Peter Gibson J distinguished between

(i) actual knowledge;

(ii) wilfully shutting one's eyes to the obvious;

(iii) wilfully and recklessly failing to make such inquiries as an honest and reasonable man would make;

(iv) knowledge of circumstances which would indicate the facts to an honest and reasonable man; and

(v) knowledge of circumstances which would put an honest and reasonable man on inquiry.

Smellie J held that the proviso to s 18(1) would apply only if type (iii) knowledge could be shown to have existed - which sets a higher bar than the type (v) knowledge required by the common law. With respect, it is submitted that Smellie J's adoption of the categorisation in the Baden, Delvaux case unnecessarily complicated the law and, by adopting a narrower test of knowledge than the common law, shifted the balance so as to be unduly favourable to $3^{\text {rd }}$ parties. (Note 30 )

Apart from judicial interpretation of the concept of 'knowledge', the text of s 18(1) itself limits the circumstances in which a company can argue that a $3^{\text {rd }}$ party is not entitled to assume authority. This it does by limiting the circumstances in which a company can claim that a $3^{\text {rd }}$ party ought to have had knowledge of the agent's lack of authority only to circumstances where that knowledge stemmed from the $3^{\text {rd }}$ party's 'position with or relationship to' the company. (Note 31 ) I would argue that this too unduly favours $3^{\text {rd }}$ parties, as there would be many cases in which $3^{\text {rd }}$ parties with no prior relationship with the company ought reasonably to have known that knowledge did not exist, simply because of the circumstances of the transaction. An obvious situation is where, even without any prior connection to the company, a reasonable person would find the transaction suspicious. Should a $3^{\text {rd }}$ party be allowed to close their eyes to suspicious circumstances and avail of s 18(1) simply because they have no prior relationship with the company? For example, if the facts of Northside Developments Pty Ltd v Registrar-General (Note 32) were to arise in New Zealand, would a company be liable to a lender who had no prior relationship with the company where the company's agent had taken out a loan which was of no benefit to the company and in relation to which an honest and reasonable lender would have made inquiries yet failed to do so?

Thus $\mathrm{s}$ 18(1) has changed the law relating to the indoor management rule so that it is significantly different from the common law by (i) requiring that prove more than that a $3^{\text {rd }}$ party was put on their inquiry and (ii) requiring that the $3^{\text {rd }}$ party's knowledge stem from a position in or relationship with the company. It is submitted that these two factors unduly skew the law in favour of $3^{\text {rd }}$ parties.

\section{People's Republic of China}

What would be the position in the PRC if a 3rd party entered into a contract with an agent of a company where that agent lacked authority? Would the 3rd party be able to hold the company liable? It is useful to consider two statutory provisions and cases that have arisen under them: Articles 49 and 50 of the Contract Law of the People's Republic of China (Note 33) and Article 16 of the Company Law of the People's Republic of China. (Note 34)

\subsection{Articles 49 and 50 of the Contract Law}

First, the fact that a purported agent lacks actual authority would not be a bar to liability on the part of the principal, as the doctrine of apparent authority is recognised in Chinese Law. Article 49 of the Contract Law states 
Article 49 - Where an actor enters, without the right of agency, in excess of the right of agency or beyond the expiration of the right of agency, into a contract in the name of a principal, and where the counterpart has grounds to believe that the actor has the right of agency, the act of agency shall be deemed as effective

In 2009 the Supreme People's Court issued the Guiding Opinion on Several Questions Concerning the Trial of Civil and Commercial Contract Disputes (Note 35) Section IV of the Guiding Opinion states as follows:

The system of agency by estoppel provided in Article 49 of the Contract Law shall require that not only the unauthorized agency of the agent objectively appear to be duly authorized, but also the opposite party be subjectively in good faith and be irreproachable in believing that the performer has the power of attorney. The opposite party of the contract who alleges the agency by estoppel shall assume the burden of proof to not only prove objective appearance elements, such as contract, official seal and personal seal supporting existence of authorized agency, but also prove that he/she is subjectively in good faith and irreproachable in believing that the performer has power of attorney.

This Guiding Opinion thus indicates that a $3^{\text {rd }}$ party seeking to hold a principal liable on the basis of apparent authority needs to prove that they (the $3^{\text {rd }}$ party) objectively believed that the purported agent had authority and also that they were acting in good faith. The stipulation of good faith is puzzling in that if a party has proved that it was reasonable for them to believe that the apparent agent would have authority, they must, by doing so, have impliedly demonstrated good faith. Or, to put it differently, objective belief could not exist in the absence of good faith, and lack of good faith would preclude a finding of objective belief. It may however be the case that what the Guiding Opinion is seeking to emphasise is that the $3^{\text {rd }}$ party must prove the existence both of objective, external facts which would give rise to a reasonable belief as well as show that they acted in good faith on the basis of that reasonable belief - in other words, that the 'subjective' requirement is the equivalent of bona fide reliance in the common law.

So far as the acts of a representative of a company are concerned, Article 50 of the Contract Law states as follows:

Article 50 - Where a legal person, or the legal representative or the person in charge of an organization exceeds the limits of power in making a contract, the act of representation shall be effective unless the counterpart is aware or ought to be aware of the excess of the limit of power.

Academic commentary supports the argument that the effect of Article 50 is to remove the doctrine of ultra vires from Chinese company law, at least in so far as it applies to company contracts with $3^{\text {rd }}$ parties. (Note 36 ).

The use of the phrase 'is aware or ought to be aware' in Article 50 indicates that under the law of the PRC either actual knowledge or knowledge which a reasonable person would have had, will displace the reliance that a $3^{\text {rd }}$ party could otherwise place on the authority of a company agent. Do courts in the PRC apply a test similar to the 'put on inquiry' test under the common law? Although that phrase is not used in China, there are cases which suggest that the outcome of a case decided in China would be the same as decided in the Hong Kong SAR or in Singapore.

In Shanghai Pele Communication Development Co., Ltd. v West Securities Co., Ltd., Shanghai Kailu Road Sales Department of West Securities Co., Ltd. \& West Securities Co., Ltd., (Note 37) where two agents of the defendant company agent had entered into a contract with the plaintiff after their authority had expired, the court used an objective test in applying Articles 49 and 50 of the Contract Law. The court held that the defendant was contractually bound by its agents' actions because of the positions they held in the company and because they had previously represented the defendant in transactions with the plaintiff, and so it was justifiable for the plaintiff to believe they had authority.

By contrast, in China Construction Bank v Yantai First Paper Group Corporation Limited, (Note 38) the appellant bank was held not to be entitled to rely on the purported authority of an agent of the respondent who had entered into loan contracts where the loaned funds were to be credited to an unrelated company and where the loan amounts were in excess of the respondent company's issued capital, the court held that the contract was invalid. This case bears interesting parallels to the Australian case of Northside Developments Pty Ltd $v$ Registrar-General (Note 39) and the Hong Kong case of Akai Holdings Ltd (In Liquidation) v Thanakharn Kasikorn Thai Chamkat (Mahachon) also known as Kasikorn Bank Public Co Ltd, (Note 40) in both of which, it will be remembered, a lender was held unable to enforce a loan contract which was of no benefit to the company on whose behalf the agent was acting.

In Shanghai Nanshi Branch of China Industrial Bank v Chen Baihui, Shanghai Yilin Paper Products Decoration 
Co., Ltd., Shanghai Zhongrong Industry \& Commerce Co., Ltd., Shanghai Pudong Xiechuang Ostrich Property Co., Ltd. \& Shangqiu Lantian Branch of Bank of China Co., Ltd, (Note 41) a guarantee had been entered into on behalf the fourth respondent by its Deputy President, who had misused the company's seal. The court held that both the agent's position in the company and the fact that he had been able to use its seal gave reasonable grounds for the appellant to believe that he had authority, and that in the absence of any prior information from the fourth respondent as to what internal processes it might have for the authorisation of such guarantees, the appellant there were no grounds upon which it could be argued that the appellant ought to have been aware that the agent was acting without authority.

Similarly, in Bank of China (Hong Kong) v Hongye Company, (Note 42) where the appellant was seeking to enforce a guarantee contract entered into by the respondent, and agents of the respondent had presented the appellant with minutes of a board meeting stamped with the company's seal which indicated authority to enter into the guarantee, the court held that despite the fact that the board minutes were invalid, the guarantee was still binding on the respondent, because it was reasonable for the appellant bank to believe that authority had been given.

It is submitted that the last two cases provide excellent examples arising from PRC law of the application of the same principle which, in common law jurisdictions, is contained in the Turquand rule and which leads to contract being affirmed despite a defect in internal company proceedings.

\subsection{Article 16 of the Company Law}

Article 16 of the Company Law of the People's Republic of China (Note 43) states as follows:

Article 16 - If a company invests in another enterprise or provides security for another party, a resolution shall be adopted by the board of directors or by the board of shareholders or general meeting according to the provisions of the articles of association of the company. If the articles of association of the company have specified a limit on the total amount of investment or security and the amount of a single investment or security, the specified limit may not be exceeded.

If a company provides security for a shareholder or the de facto controller of the company, a resolution of the board of shareholders or general meeting shall be passed.

Any shareholder set forth in the preceding paragraph or controlled by a de facto controller set forth in the preceding paragraph may not participate in voting on any resolution specified in the preceding paragraph. Such resolution shall be adopted by the other shareholders that are present at the meeting and represent more than half of the voting rights.

On the face of it, Article 16 would appear not to relate to the validity of unauthorised contracts entered into by company agents, as its essence is to place a prohibition on companies either entering into security guarantees without complying with the procedures mandated by the Article, or in excess of limits imposed by the company's internal governing document. However, Article 16 has been interpreted in a manner which gives it the same effect in Chinese law as the Turquand rule has under the common law.

In China National Building Materials Import \& Export Group Corporation v. Beijing Lang \& Overseas Trading Co., Ltd., Beijing Tianyuan Shengtang Investment Co., Ltd., Glory Century Technologies Development (Beijing) Co., Ltd., Jiangsu Yinda Technologies Co., Ltd., and Sichuan Yibin E'ou Engineering Development Co., Ltd, (Note 44) the court considered a case where the representative of the fourth respondent (Jiangsu Yinda Technologies Co., Ltd ) had signed a guarantee in favour of the appellant. The fourth respondent argued that it was not bound by the contract because its agent had signed the guarantee without obtaining the consent of the board of directors, as required by Article 16. The court held that while it was a breach of Article 16 for a company to enter into a guarantee contract without the consent of the directors, the Article did not expressly state that contracts entered into in breach of it would be invalid and that non-compliance with internal procedures should not affect the rights of $3^{\text {rd }}$ parties as that would lead to uncertainty in contract law. The court also stated that it would be neither workable nor reasonable to impose on $3^{\text {rd }}$ parties an obligation to check that the internal processes of a company had been complied with. The court therefore declared the contract to be valid. The consistency of this reasoning with the way in which a court in a common law jurisdiction would apply the Turquand rule is obvious.

The second case is not one in which Article 16 was referenced directly, but it is nevertheless another example of a case in which a Chinese court has held that non-compliance with internal formalities will not vitiate a contract entered into on behalf of a company by someone who otherwise appears to be its agent: In Beijing Gongda Real Estate Co Ltd v Beijing Xianghesanxia Real estate Development Co Ltd (Note 45) an agent of the respondent had 
signed a contract for the assignment of a real-estate development contract with the appellant company. The respondent's agent, who was publically registered as a representative of the company, had been suspended from duty prior to his entering into the contract on the company's behalf. However, the company had not taken the step of removing his name from the public register. The Supreme People's court upheld the validity of the contract, stating that "an internal personnel adjustment" by the respondent company did not affect the validity of the contract where, to outsiders, a person was reflected as being an agent of the company. Thus this case is another example of the adoption of an approach in China which would be recognised by overseas lawyers as being identical to the reasoning in Turquand.

\section{Analysis and a Suggested Model Provision}

The survey of the various jurisdictions discussed in this article supports a number of conclusions:

Hong Kong and Singapore have left the issue of whether a $3^{\text {rd }}$ party can hold a company liable for the acts of an unauthorised agent wholly to the common law and, through judicial interpretation, continue to deny $3^{\text {rd }}$ parties protection only where a reasonable person would be put on their inquiry. This, I would argue, is the test which best strikes the balance between the interests of principals (for the purpose of this paper, principals which are corporations) and the interests of $3^{\text {rd }}$ parties entering into transactions with corporations. It is also the test which, I would submit, best serves the interest of commercial convenience and practicality, in that it places the burden on corporations to ensure compliance with their internal proceedings of which they of course have particular knowledge, rather than requiring $3^{\text {rd }}$ parties to determine what those processes are and whether they have been complied with.

By contrast, in the process of putting into statutory form the rules relating to the authority of company agents and the circumstances in which $3^{\text {rd }}$ parties may assume compliance with internal company proceedings, the legal systems in Australia and New Zealand have disturbed the balance. In the case of Australia, s 128(4) of the Corporations Act 2001 (Cth) unduly favours $3^{\text {rd }}$ parties because it has abandoned the common law test of objective suspicion and requires companies to prove that $3^{\text {rd }}$ parties subjectively suspected that company agents lacked authority. In New Zealand, s 18(1) of the Companies Act 1993 (NZ) also unduly favours $3^{\text {rd }}$ parties by limiting the circumstances in which a company can claim that a $3^{\text {rd }}$ party ought to have had knowledge of the agent's lack of authority to circumstances where that knowledge stemmed from the $3^{\text {rd }}$ party's 'position with or relationship to' the company. Furthermore, the courts have interpreted $\mathrm{s}$ 18(1) in such a way as to overly-complicate the concept of reasonableness and now require companies to prove a higher level of suspicion (wilful and reckless failure to inquire) than is required by the common law.

Interestingly, the civil law system in the PRC has, through judicial interpretation of Articles 49 and 50 of the Contract Law and Article 16 of the Company Law, independently arrived at a position which is the same as the common law, in that it applies the same test of reasonableness of belief as does the common law both when determining whether a third party has proved apparent authority and when determining whether a $3^{\text {rd }}$ party should be able to assume that internal company processes have been complied with. Perhaps this is unsurprising - the reasonableness test strikes an appropriate balance between companies and $3^{\text {rd }}$ parties and is also consistent with practical commercial considerations.

Given the frequency with which companies from different jurisdictions enter into contracts, and the obvious importance to such contracts of the authority of company agents, it would clearly be useful were jurisdictions to adopt a uniform approach to this question. Therefore it is submitted that the following constitutes a suitable articulation of principles for courts in jurisdictions applying the common law, and a suitable text for an enactment in jurisdictions which seek to put the law into statutory form. In the case of the jurisdictions surveyed in this article, the proposed test would be consistent with the law as it currently stands under the common law in Singapore, Hong Kong and under statutes in the PRC, but would require the repeal of the statutory currently in force in Australia and New Zealand in order to restore the balance between companies and $3^{\text {rd }}$ parties contracting with them:

Where a person has been held out by a company as being an officer or agent of the company, a person dealing with the company may assume that that officer or agent has been validly appointed, has the authority to enter into transactions usually entered into by an officer or agent holding the same position in a company of that type, and is complying with the law, with instructions and with the company's internal governing document, unless the company can prove that the person dealing with the company knows that the relevant assumption is not true, or that a person in the position of that person would reasonably suspect that it might not be true and would make inquiries as to the truth of the assumption. 


\section{References}

Austin, R., \& Ramsay, I. (2013). Ford's Principles of Corporations Law (15th ed.). Chatswood, Lexis-Nexis.

Farrar, J. (Ed.). (2013). Company and Securities Law in New Zealand (2nd ed.). Wellington, Brookers.

Gu, M. (2010). Understanding Chinese Company Law (2nd ed.). Hong Kong, Hong Kong University Press.

Lipton, L., Herzberg, A., \& Walsh, M. (2013). Understanding Company Law (17th ed.). Sydney, Thomson-Reuters.

Parliament of Australia, House of Representatives. (1997). Company Law Review Bill 1997 - Explanatory Memorandum (1997). Retrieved from http://www.comlaw.gov.au/Details/C2004B01817.

Reynolds, F. M. B. (2006). Bowstead and Reynolds on Agency (18th ed.). London, Sweet \& Maxwell.

Tan, C. H. (2009). Walter Woon on Company Law (3rd ed.). Singapore, Sweet \& Maxwell.

Walker, G., Pekmezovic, A., Hanrahan, P., Ramsay, I., \& Stalpledon, G. (2012). Commercial Applications of Company Law in New Zealand (4th ed.). Auckland, $\mathrm{CCH}$.

\section{Notes}

Note 1. For a general discussion on types of authority see F M B Reynolds Bowstead and Reynolds on Agency (18 ${ }^{\text {th }}$ ed, Sweet $\&$ Maxwell, London, 2006) pp. 105-36 and 335-61.

Note 2. The leading case on apparent authority of company agents is Freeman and Lockyear $v$ Buckhurst Park Properties (Mangal) Ltd [1964] 2 QB 480.

Note 3. (1856) 119 ER 886.

Note 4. Interestingly, the legislation makes no provision for contracts entered into without writing or speech, as many contracts of course are - one need only think of the example of a customer at a supermarket purchasing goods through an automatic checkout, or from a checkout assistant in circumstances where neither the customer nor the assistant say anything.

Note 5. [2010] KKCFA 63; (2010) 13 HKCFAR 479; [2011] 1 HKC 357.

Note 6. Ibid, [62]. Ma CJ, Bokhary, Chan PJ and Ribiero PJ concurred in the judgment of Lord Neuberger.

Note 7. Ibid [59].

Note 8. Ibid [61].

Note 9. Ibid [81].

Note 10. Ibid, [82-86].

Note 11. In this regard, the case is very similar to the Australian case of Northside Developments Pty Ltd $v$ Registrar-General (1989-1990) 170 CLR 146, in which it was held not to be reasonable for a third-party lender to believe that an agent of a company had authority to enter into a guarantee contract which was of no benefit to that company.

Note 12. Akai [94].

Note 13. [2009] SGHC 197. Note that the case was unsuccessfully appealed (see Skandinaviska Enskilda Banken AB (Publ), Singapore Branch v Asia Pacific Breweries (Singapore) Pte Ltd [2011] 3 SLR 540) but with no reference to the Turquand rule.

Note 14. Ibid, [92].

Note 15. C H Tan Walter Woon on Company Law ( $3^{\text {rd }}$ ed, Sweet \& Maxwell, Singapore, 2009), pp. 99-103.

Note 16. [1946] AC 459, 475 (Simonds LJ).

Note 17. (1990) 170 CLR 146.

Note 18. For a discussion of the Northside decision see R Austin and I Ramsay Ford's Principles of Corporations Law (15 $5^{\text {th }}$ ed, Lexis-Nexis, Chatswood, 2013), p. 922.

Note 19. Ibid, p 907.

Note 20. Ibid, pp 926-27 and 929. See also P Lipton, A Herzberg and M Walsh Understanding Company Law (17 $7^{\text {th }}$ ed, Thomson-Reuters, Sydney 2013), pp. 161-62. 
Note 21. See Austin and Ramsay (note 18 above), p. 927.

Note 22. Parliament of Australia, House of Representatives Company Law Review Bill 1997 - Explanatory Memorandum (1997) Para. 8.7, available at http://www.comlaw.gov.au/Details/C2004B01817.

Note 23. The reference to 'the current law' in the Explanatory Memorandum was to s 164(4)(b) of the Corporations Law, the predecessor of the Corporations Act 2001 (Cth). Section 164(4)(b) had provided that a $3^{\text {rd }}$ party lost their right to assume that a company agent had authority where

..the person's connection or relationship with the company is such that the person ought to know that the matter that, but for this subsection, the person would be entitled to assume is not correct.

The only difference between the test in s 164(4)(b) and the common law was the fact that its application was confined to persons who had a connection to or relationship with the company. Otherwise, s 164(4)(b) was consistent with the common law in that by using the word 'ought', it required that a company seeking to deny liability had to prove that the $3^{\text {rd }}$ party objectively knew or suspected that the agent lacked authority and thus was put on his or her inquiry.

Note 24. [2003] VSC 315, [118-119].

Note 25. [2005] SASC 335, [178].

Note 26. See Lipton, Herzberg and Walsh (above n 20), p. 162.

Note 27. [1998] 2 NZLR 481.

Note 28. Ibid 630.

Note 29. [1993] 1 WLR 509, 575-76.

Note 30. For a discussion of the Equiticorp case see John Farrar (ed) Company and Securities Law in New Zealand, (2 ${ }^{\text {nd }}$ ed, Brookers, Wellington, 2013), pp. 137-38.

Note 31. See A Pekmezovic et al Commercial Applications of Company Law in New Zealand $\left(4^{\text {th }}\right.$ ed, CCH, Auckland, 2012), pp. 462-63.

Note 32. (1990) 170 CLR 146.

Note 33. Adopted by the Ninth People's Congress, 15 March 1999.

Note 34. Note 34.

Note 35. Supreme People's Court, Document [2009] No. 40, 7 July 2009.

Note 36. See, for example, Minkang Gu Understanding Chinese Company Law $\left(2^{\text {nd }}\right.$ ed, Hong Kong University Press, Hong Kong, 2010), p. 67.

Note 37. Shanghai Second Intermediate Court, Third Civil Division (Commercial Case), Initial Ruling, Case No. 286, 25 May 2005.

Note 38. People's Court, Economic Division, Final Ruling, Case No., 138, 29 November 2001.

Note 39. (1990) 170 CLR 146.

Note 40. [2010] KKCFA 63; (2010) 13 HKCFAR 479; [2011] 1 HKC 357.

Note 41. Shanghai High Court, Second Civil Division (Commercial Case), Final Ruling, Case No. 167, 10 October 2005.

Note 42. Supreme People's Court, Trial at Second Instance, 9 July 2004 [SPC Gazette, Issue 7, 2005].

Note 43. Adopted by the 8th National People's Congress on December 29, 1993.

Note 44. Higher People's Court of Beijing, Trial at Second Instance, 22 September 2009, [SPC Gazette, Issue 2, 2011].

Note 45. Supreme People's Court, Retrial, 12 December 2009 [SPC Gazette, Issue 11, 2010].

\section{Copyrights}

Copyright for this article is retained by the author(s), with first publication rights granted to the journal.

This is an open-access article distributed under the terms and conditions of the Creative Commons Attribution license (http://creativecommons.org/licenses/by/3.0/). 